\title{
Post-Irradiation Fracture Toughness Characterization of Generation II FeCrAI Alloys
}

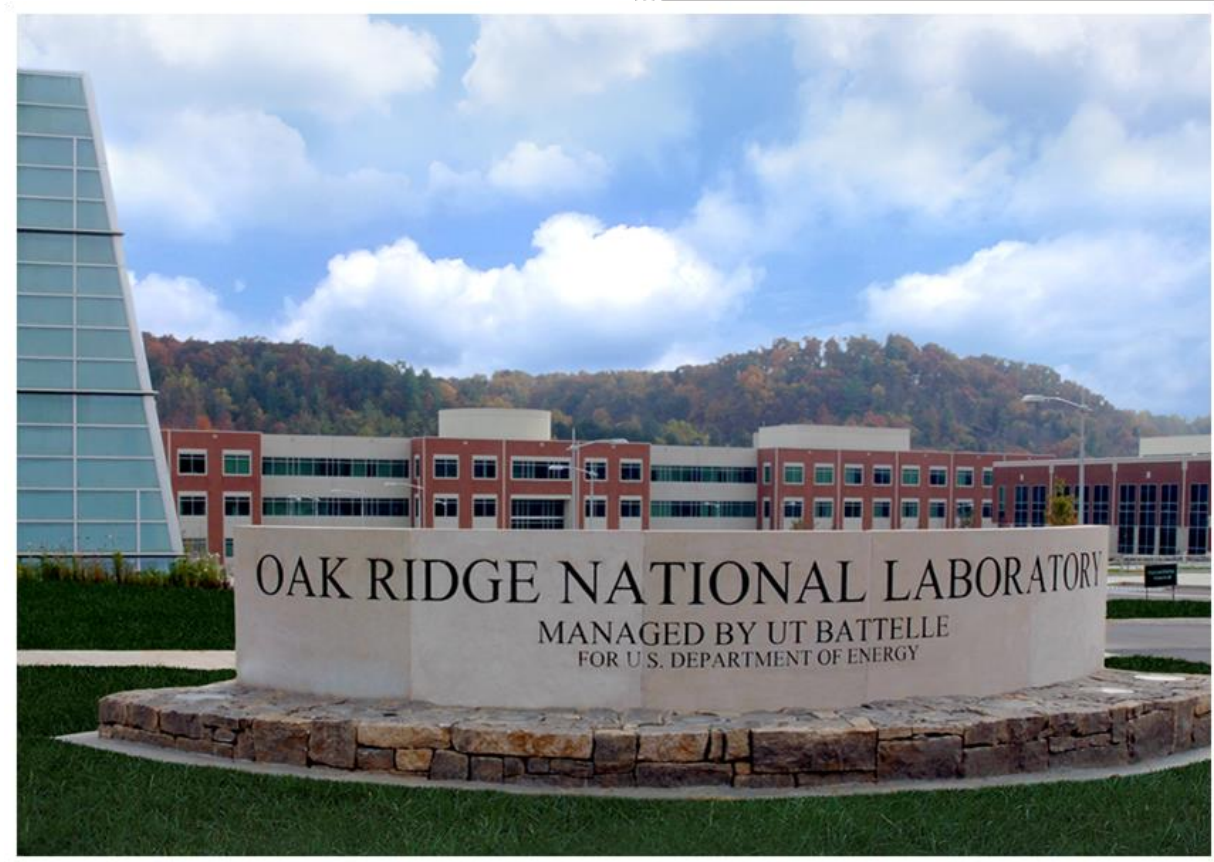

Approved for public release. Distribution is unlimited.
X. Chen ${ }^{1}$, K.G. Field ${ }^{1,2}$,

D. Zhang ${ }^{1,3}$, C. Massey ${ }^{1}$, J.P. Robertson ${ }^{1}$, K. Linton ${ }^{1}$, A. Nelson ${ }^{1}$

${ }^{1}$ Oak Ridge National Laboratory ${ }^{2}$ Now at University of Michigan ${ }^{3}$ Now at Pacific Northwest National Laboratory

October 2019 


\title{
DOCUMENT AVAILABILITY
}

Reports produced after January 1, 1996, are generally available free via US Department of Energy (DOE) SciTech Connect.

Website www.osti.gov

Reports produced before January 1, 1996, may be purchased by members of the public from the following source:

\author{
National Technical Information Service \\ 5285 Port Royal Road \\ Springfield, VA 22161 \\ Telephone 703-605-6000 (1-800-553-6847) \\ TDD 703-487-4639 \\ Fax 703-605-6900 \\ E-mail info@ntis.gov \\ Website http://classic.ntis.gov/
}

Reports are available to DOE employees, DOE contractors, Energy Technology Data Exchange representatives, and International Nuclear Information System representatives from the following source:

Office of Scientific and Technical Information

PO Box 62

Oak Ridge, TN 37831

Telephone 865-576-8401

Fax 865-576-5728

E-mail reports@osti.gov

Website http://www.osti.gov/contact.html

This report was prepared as an account of work sponsored by an agency of the United States Government. Neither the United States Government nor any agency thereof, nor any of their employees, makes any warranty, express or implied, or assumes any legal liability or responsibility for the accuracy, completeness, or usefulness of any information, apparatus, product, or process disclosed, or represents that its use would not infringe privately owned rights. Reference herein to any specific commercial product, process, or service by trade name, trademark, manufacturer, or otherwise, does not necessarily constitute or imply its endorsement, recommendation, or favoring by the United States Government or any agency thereof. The views and opinions of authors expressed herein do not necessarily state or reflect those of the United States Government or any agency thereof. 
Advanced Fuels Campaign

\title{
POST-IRRADIATION FRACTURE TOUGHNESS CHARACTERIZATION OF GENERATION II FECRAL ALLOYS
}

\author{
Xiang (Frank) Chen ${ }^{1}$, Kevin G. Field ${ }^{1,2}$, Dalong Zhang ${ }^{1,3}$, Caleb P. Massey ${ }^{1}$, Kory D. Linton ${ }^{1}$, \\ Janet P. Robertson ${ }^{1}$, Andrew T. Nelson ${ }^{1}$ \\ ${ }^{1}$ Oak Ridge National Laboratory \\ ${ }^{2}$ Now at University of Michigan \\ ${ }^{3}$ Now at Pacific Northwest National Laboratory
}

Date Published: October 2019

Prepared by

OAK RIDGE NATIONAL LABORATORY

Oak Ridge, TN 37831-6283

managed by

UT-BATTELLE, LLC

for the

US DEPARTMENT OF ENERGY

under contract DE-AC05-00OR22725 



\section{CONTENTS}

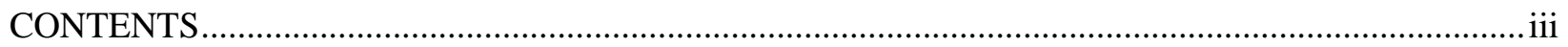

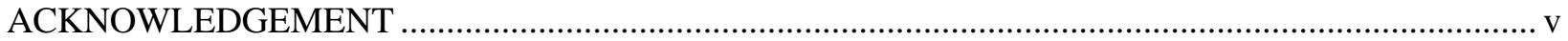

EXECUTIVE SUMMARY ................................................................................................ vii

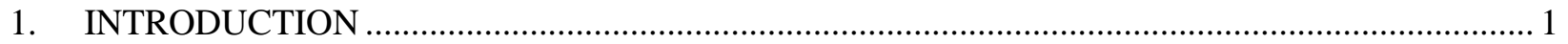

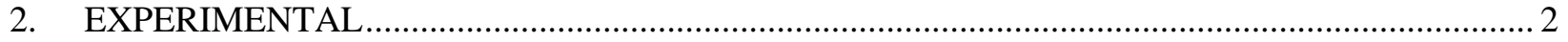

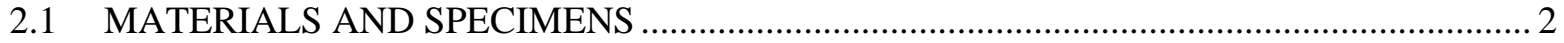

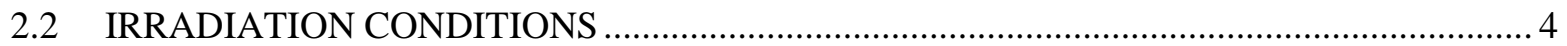

2.3 TESTING TECHNIQUE AND EQUIPMENT …..................................................... 5

2.3.1 Vickers Microhardness ....................................................................... 5

2.3.2 Master Curve Transition Fracture Toughness .................................................6 6

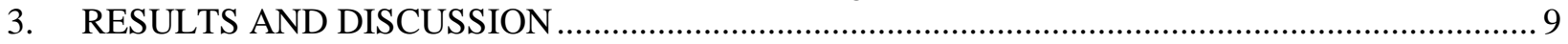

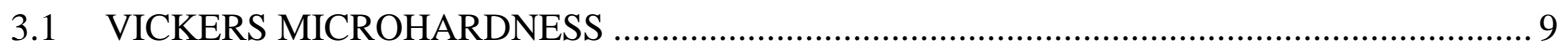

3.2 TRANSITION FRACTURE TOUGHNESS ........................................................... 10

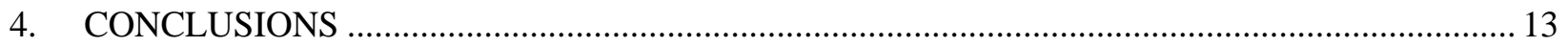

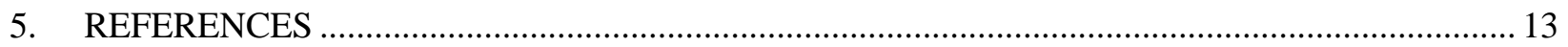




\section{ACKNOWLEDGEMENT}

This research was sponsored by the U.S. Department of Energy, Office of Nuclear Energy, Advanced Fuels Campaign Program, under contract DE-AC05-00OR22725 with UT-Battelle, LLC. A portion of this research at High Flux Isotope Reactor of Oak Ridge National Laboratory (ORNL) was sponsored by the Scientific User Facilities Division, Office of Basic Energy Sciences, US Department of Energy.

We are grateful for Eric Manneschmidt and Ronald Swain from ORNL for performing portions of the fracture toughness testing reported within. We also appreciate Clay Morris and Mark Delph from the Irradiated Materials Examination and Testing facility at ORNL in arranging and facilitating hot cell testing. Lastly, we would like to thank Lizhen Tan and Yukinori Yamamoto for their thoughtful review of this report prior to publication. 


\section{EXECUTIVE SUMMARY}

FeCrAl alloys are promising candidate materials for the accident tolerant fuel (ATF) cladding applications due to their excellent corrosion resistance to the elevated temperature steam environment. Currently, the handbook on $\mathrm{FeCrAl}$ material properties contains only limited data regarding the fracture toughness properties of any $\mathrm{FeCrAl}$ alloy, let alone alloys currently under investigation within the Advanced Fuels Campaign (AFC) such as the Oak Ridge National Laboratory (ORNL) derived FeCrAl alloys. In this project, a series of irradiation capsules have been irradiated in the High Flux Isotope Reactor (HFIR) with two candidate Generation II FeCrAl alloys, i.e., C06M and C36M, to assess the fracture response of these alloys after neutron irradiation. These alloys represent the "book-end" compositions for C26M, the alloy currently being developed as the leading candidate for LWR cladding. A total of six irradiation capsules were irradiated in HFIR at target temperatures of $200^{\circ} \mathrm{C}, 330^{\circ} \mathrm{C}$, and $500^{\circ} \mathrm{C}$ up to target damage doses of 8 displacements per atom (dpa) and $16 \mathrm{dpa}$. Damage doses represent the expected middle and end of life damage for typical LWR cladding while the temperature regimes will provide insight into the role of varying microstructural features on the fracture toughness properties of neutron irradiated $\mathrm{FeCrAl}$ alloys. To date, all capsules have completed irradiation within HFIR. This report summarizes the post-irradiation fracture toughness testing results for the 8 dpa capsules.

We performed post-irradiation fracture toughness characterization on two Generation II FeCrAl alloys, i.e., $\mathrm{C} 06 \mathrm{M}$ and $\mathrm{C} 36 \mathrm{M}$. The measured irradiation conditions were: $501^{\circ} \mathrm{C} / 6.6 \mathrm{dpa}, 315^{\circ} \mathrm{C} / 7.9 \mathrm{dpa}$, and $166^{\circ} \mathrm{C} / 6.6 \mathrm{dpa}$. Main conclusions of this study can be summarized as followings:

1) For the unirradiated condition, the Master Curve fracture toughness transition temperature $T_{0}$ was $110^{\circ} \mathrm{C}$ for $\mathrm{C} 06 \mathrm{M}$ and $188^{\circ} \mathrm{C}$ for $\mathrm{C} 36 \mathrm{M}$.

2) Irradiations at $501{ }^{\circ} \mathrm{C}$ and $315^{\circ} \mathrm{C}$ resulted in small changes in $\mathrm{T}_{0}$ from the unirradiated condition for both C06M and C36M.

3) Significant irradiation embrittlement was observed for both $\mathrm{C} 06 \mathrm{M}$ and $\mathrm{C} 36 \mathrm{M}$ for the irradiation at $166^{\circ} \mathrm{C}$ where $\mathrm{T}_{0}$ raised to $303^{\circ} \mathrm{C}$ for $\mathrm{C} 06 \mathrm{M}$ and $265^{\circ} \mathrm{C}$ for $\mathrm{C} 36 \mathrm{M}$.

4) A reasonable linear correlation between the Master Curve fracture toughness transition temperature $\mathrm{T}_{0}$ and Vickers microhardness was observed for both C06M and C36M with C06M showing a steeper increase in $\mathrm{T}_{0}$ for the same amount of irradiation hardening. 


\section{INTRODUCTION}

Currently, the handbook on FeCrAl material properties [1] contains only limited data regarding the fracture toughness properties of any $\mathrm{FeCrAl}$ alloy, let alone alloys currently under investigation within the Advanced Fuels Campaign (AFC) such as the Oak Ridge National Laboratory (ORNL) derived FeCrAl alloys. Unirradiated datasets developed both by ORNL [2] and previously within literature [3] using Charpy V-notch specimens to determine the ductile to brittle transition temperature (DBTT) showed key findings including (i) increasing $\mathrm{Al}$ and/or Cr content can raise the DBTT of FeCrAl alloys, (ii) DBTT values can typically reside at or above room temperature for $\mathrm{FeCrAl}$ alloys, and (iii) grain size and residual strain can have an effect on the fracture properties. These results suggest that the fracture toughness of $\mathrm{FeCrAl}$ alloys may be a factor in its deployment for nuclear power applications, but no studies have been completed prior regarding the DBTT or fracture toughness of $\mathrm{FeCrAl}$ alloys after neutron irradiation, especially for the leaner $\mathrm{Cr}$ content alloys currently under investigation as candidate alloys for light water reactor (LWR) cladding.

Taken in isolation, embrittlement of a cladding alloy during service has no bearing on possible licensure. Hydriding of zirconium cladding alloys is well understood to result in significant embrittlement.

Furthermore, mechanical failure of irradiated cladding containing fuel pellets occurs at far higher stresses than defuled cladding samples because the presence of the fuel toughens the fuel rod. Despite this absence of direct relevance to licensure, radiation embrittlement is a fundamental structure-property evolution that should be understood to guide further development of $\mathrm{FeCrAl}$ alloys. Licensure of $\mathrm{FeCrAl}$ incorporates far more complex system behaviors that will not be possible until larger quantities of fueled irradidated rodlets are available.

Recently, a series of irradiation capsules have been irradiated in the High Flux Isotope Reactor (HFIR) with candidate Generation II FeCrAl alloys to assess the fracture response of these alloys after neutron irradiation. The name of this irradiation program is the FCAB (FeCrAl-Bend Bar) irradiation program. The FCAB program irradiates the M4CVN (miniature multi-notch Charpy v-notch) bend bar geometry. Four bend bar specimens with four notches for each specimen were irradiated per capsule with two different alloys included: C06M and C36M. These alloys represent the "book-end" compositions for $\mathrm{C} 26 \mathrm{M}$, the alloy currently being developed as the leading candidate for LWR cladding. A total of six irradiation capsules were irradiated in HFIR at target temperatures of $200^{\circ} \mathrm{C}, 330^{\circ} \mathrm{C}$, and $500^{\circ} \mathrm{C}$ up to target damage doses of 8 displacements per atom (dpa) and $16 \mathrm{dpa}$. Damage doses represent the expected middle and end of life damage for typical LWR cladding while the temperature regimes will provide insight into the role of varying microstructural features on the fracture toughness properties of neutron irradiated $\mathrm{FeCrAl}$ alloys. Additional details regarding the design of the experiment for the FCAB irradiation program can be found elsewhere [4]. To date, all capsules have completed irradiation within HFIR with the 8 dpa capsules (FCAB1, FCAB3, and FCAB5) undergoing post irradiation examination, as summarized below. 


\section{EXPERIMENTAL}

\subsection{MATERIALS AND SPECIMENS}

Two Generation II FeCrAl alloys, namely C06M and C36M, were selected to study the Cr composition dependence on irradiated $\mathrm{FeCrAl}$ fracture toughness. The nominal and analyzed compositions of the two materials are summarized in Table 1.

Table 1. Nominal and analyzed compositions for C06M and C36Mf

\begin{tabular}{cccccccccccc}
\hline \multirow{2}{*}{ Alloy } & \multicolumn{10}{c}{ Composition, wt.\% } \\
\cline { 2 - 13 } & $\mathrm{Fe}$ & $\mathrm{Cr}$ & $\mathrm{Al}$ & $\mathrm{Y}$ & $\mathrm{Mo}$ & $\mathrm{Si}$ & $\mathrm{C}$ & $\mathrm{S}$ & $\mathrm{O}$ & $\mathrm{N}$ \\
\hline \multirow{2}{*}{$\mathrm{C} 06 \mathrm{M}$} & Nominal & 81.77 & 10 & 6 & 0.03 & 2 & 0.2 & & & & \\
\cline { 2 - 13 } & Analyzed & 81.80 & 10.03 & 6.00 & 0.01 & 1.96 & 0.18 & 0.0030 & 0.0012 & 0.0016 & 0.0004 \\
\hline \multirow{2}{*}{$\mathrm{C} 36 \mathrm{M}$} & Nominal & 78.77 & 13 & 6 & 0.03 & 2 & 0.2 & & & & \\
\cline { 2 - 12 } & Analyzed & 78.80 & 12.98 & 6.00 & 0.04 & 1.98 & 0.18 & 0.0030 & $<0.0003$ & 0.0016 & 0.0002 \\
\hline
\end{tabular}

A miniature four-notch Charpy bend bar specimen, called M4CVN, was used in fracture toughness characterization. Figure 1(a) illustrates the M4CVN specimen design and Figure 1(b) shows the actual machined specimens for C06M and C36M [5]. The M4CVN specimen follows the same size ratio of the bend bar specimen design in ASTM E1921 [6]. Since the loading portions are shared between neighboring notches, the M4CVN specimen design consumes less material than the standard single notch bend bar specimen and is favorable for more efficient use of irradiation facilities and reducing the specimen dose rate after irradiation. Each notch of M4CVN specimens was fatigue pre-cracked to a nominal crack size to width ratio of $\sim 0.5$ before fracture toughness testing and neutron irradiation. The fracture toughness specimens were machined from the plate material in the assumed T-L direction, i.e., the fracture plane normal direction is perpendicular to the material rolling direction and the crack propagation direction is parallel to the material rolling direction.

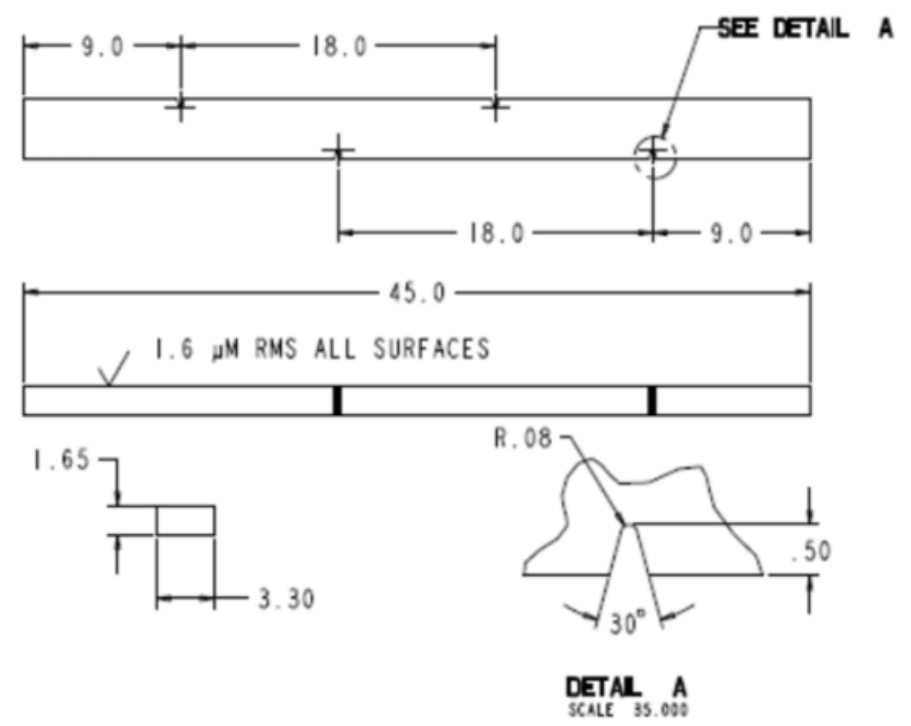

(a) 

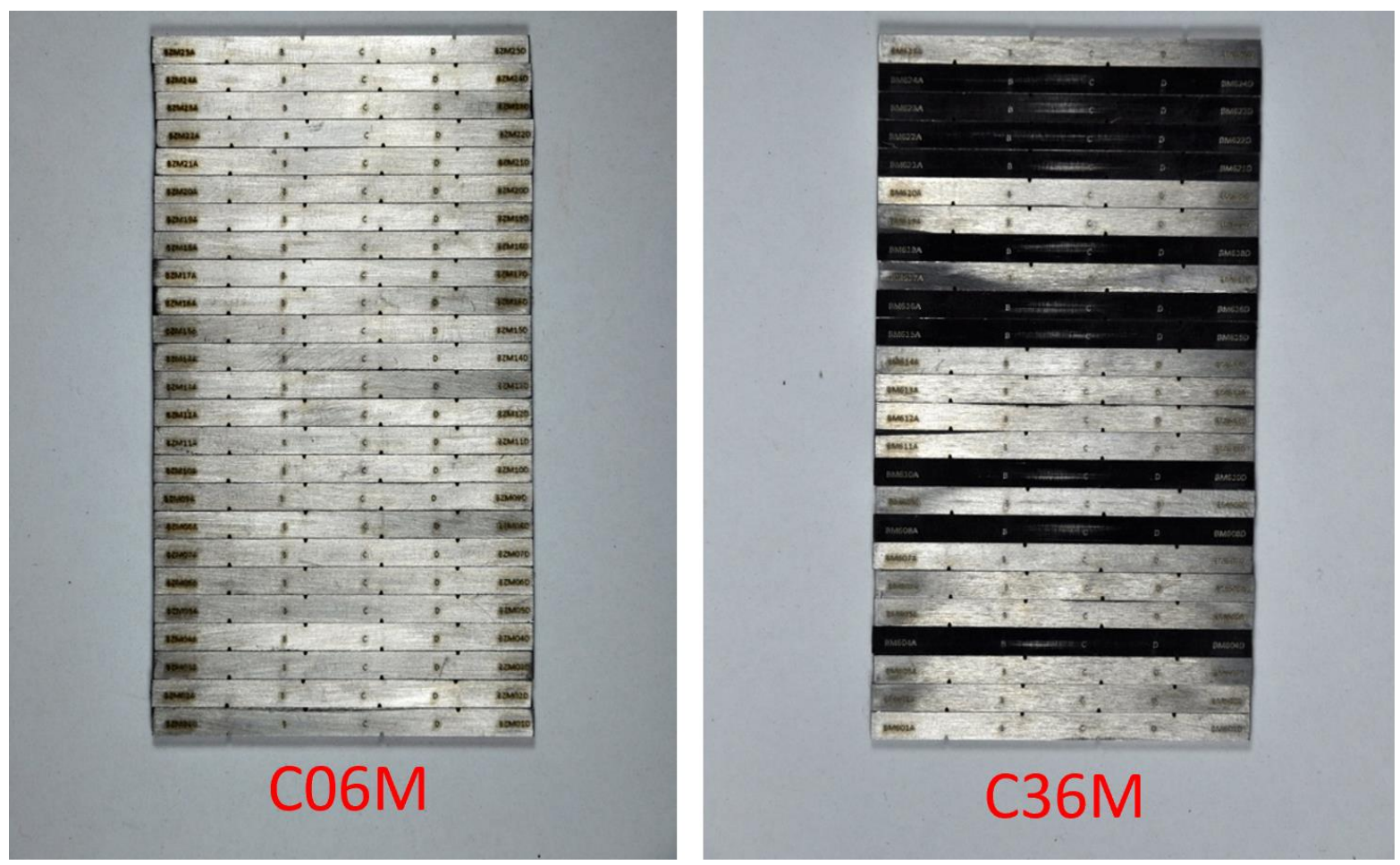

(b)

Figure 1. M4CVN specimen design in (a) and actual machined specimens in (b) [5] 


\subsection{IRRADIATION CONDITIONS}

The irradiation capsule design for the miniature four-notch Charpy bend bar specimens is illustrated below in Figure 2 and in Figure 3. Specimens were arranged such that individual SiC thermometry specimens were paired directly with each C06M or C36M specimen, and the specimens were centered within an inner housing using a spring-loaded design. A gap, filled with inert gas, allowed for identical FCAB capsules to reach different irradiation temperatures during irradiation in HFIR. All FCAB capsules were irradiated in the flux trap of HFIR, and equivalent doses were computed using the accumulated neutron fluence at each specimen location and the FeCrAl composition for each capsule. The resulting doses achieved in dpa for each FCAB capsule are given in Table 2. The irradiation temperature was measured by $\mathrm{SiC}$ thermometry specimens using a dilatometer. To determine if any significant thermal gradients existed under irradiation, the $\mathrm{SiC}$ specimens, which spanned the entire length of the irradiation capsule, were sectioned into thirds and then tested. For each capsule, one SiC specimen with all three segments were tested with an additional middle section from the three other SiC specimens tested as well. Irradiation temperatures were determined using the algorithm and methods described by Campbell et al. [7]. The resulting mean irradiation temperature is summarized in Table 2. Results show limited thermal gradients for all three capsules (less than $9 \%$ of the mean irradiation temperature) with slight deviations for the target temperatures in the low and high temperature capsules but well within the range of expected values based on the complexity of the neutron irradiation design.
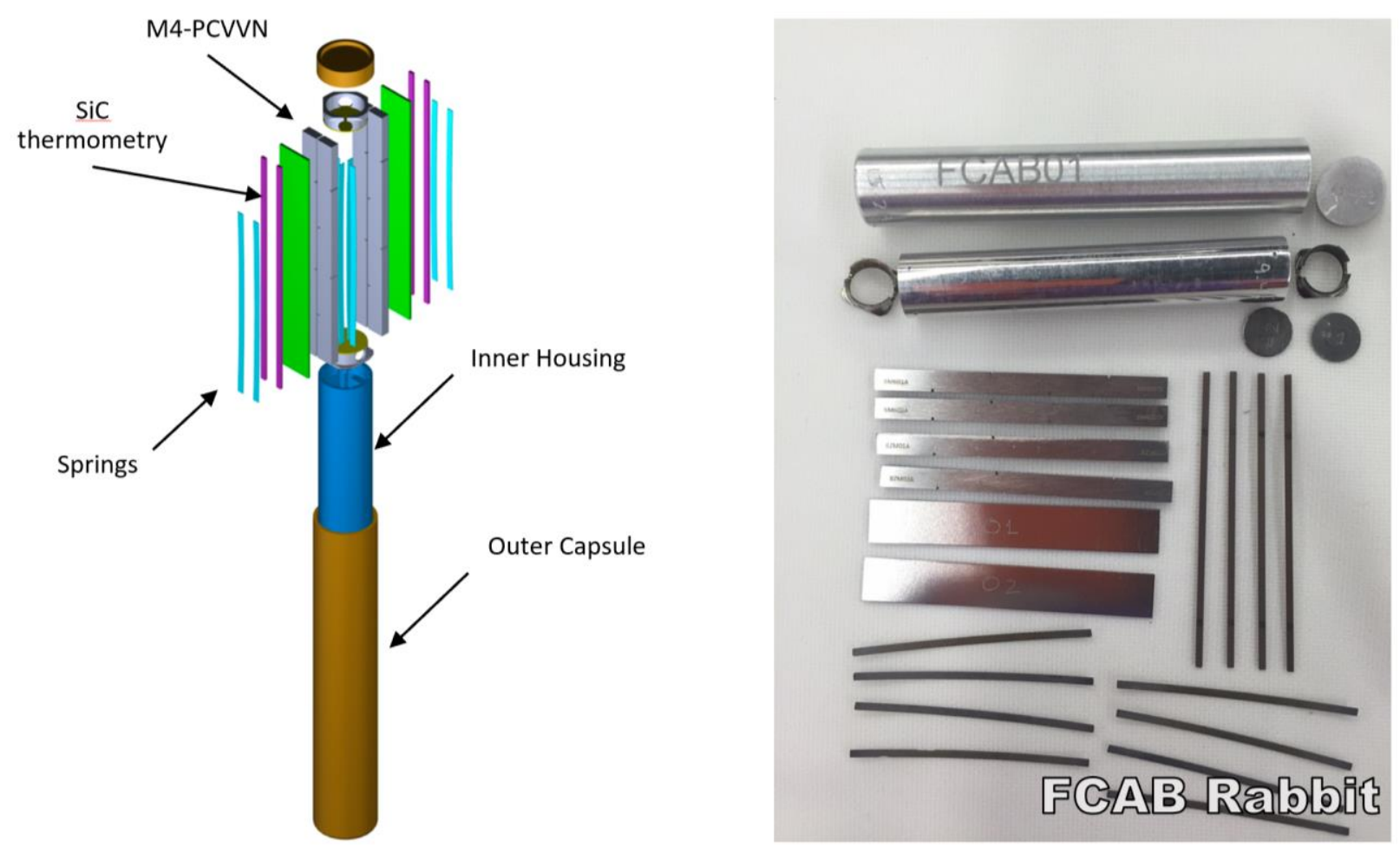

Figure 2. FCAB rabbit irradiation capsule design 

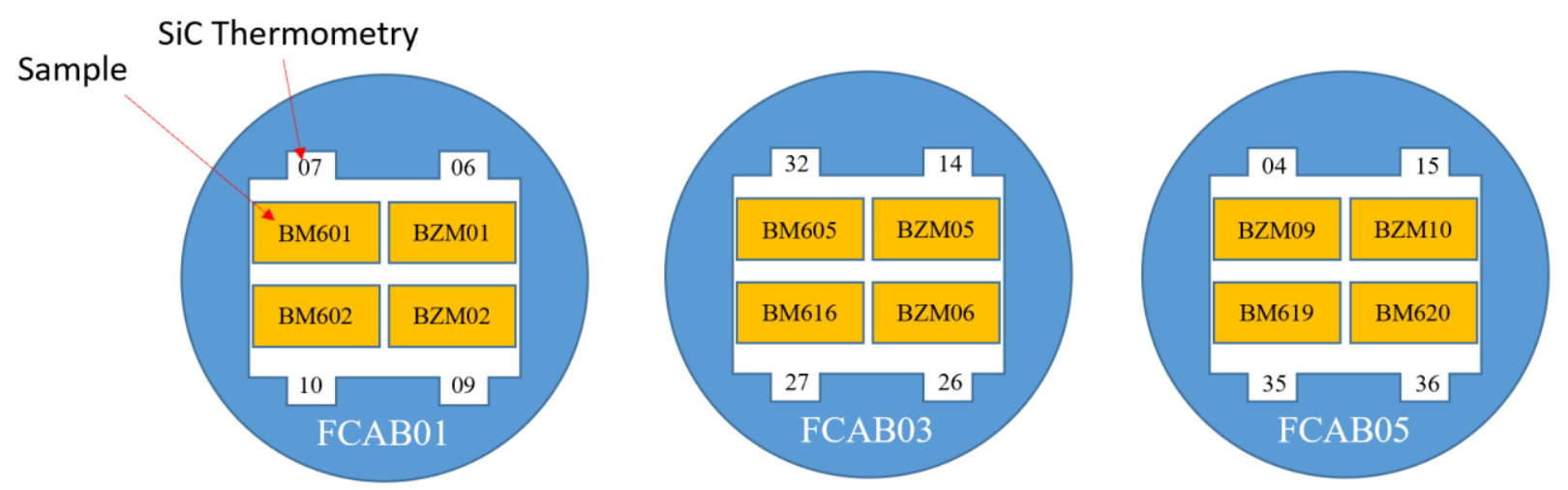

Figure 3. Arrangement of M4CVN bend bar and SiC thermometry specimens in FCAB capsules

Table 2. Summary irradiation conditions for FCAB1, FCAB3, and FCAB5 capsules

\begin{tabular}{|c|c|c|c|c|c|}
\hline Capsule & Alloys & Specimen ID & $\begin{array}{l}\text { Dose } \\
\text { (dpa) }\end{array}$ & $\begin{array}{l}\text { Target irradiation } \\
\text { temperature }\left({ }^{\circ} \mathrm{C}\right)\end{array}$ & $\begin{array}{c}\text { Average irradiation } \\
\text { temperature }\left({ }^{\circ} \mathrm{C}\right)\end{array}$ \\
\hline \multirow{2}{*}{ FCAB1 } & $\mathrm{C} 06 \mathrm{M}$ & $\begin{array}{l}\text { BZM01, } \\
\text { BZM02 }\end{array}$ & \multirow{2}{*}{6.6} & \multirow{2}{*}{200} & \multirow{2}{*}{$165.9 \pm 13.0$} \\
\hline & $\mathrm{C} 36 \mathrm{M}$ & $\begin{array}{l}\text { BM601, } \\
\text { BM602 }\end{array}$ & & & \\
\hline \multirow{2}{*}{ FCAB3 } & $\mathrm{C} 06 \mathrm{M}$ & $\begin{array}{l}\text { BZM05, } \\
\text { BZM06 }\end{array}$ & \multirow{2}{*}{7.9} & \multirow{2}{*}{330} & \multirow{2}{*}{$315.4 \pm 16.6$} \\
\hline & $\mathrm{C} 36 \mathrm{M}$ & $\begin{array}{l}\text { BM605, } \\
\text { BM616 }\end{array}$ & & & \\
\hline \multirow{2}{*}{ FCAB5 } & $\mathrm{C} 06 \mathrm{M}$ & $\begin{array}{l}\text { BZM09, } \\
\text { BZM10 }\end{array}$ & \multirow{2}{*}{6.6} & \multirow{2}{*}{550} & \multirow{2}{*}{$500.8 \pm 17.2$} \\
\hline & $\mathrm{C} 36 \mathrm{M}$ & $\begin{array}{l}\text { BM619, } \\
\text { BM620 }\end{array}$ & & & \\
\hline
\end{tabular}

\subsection{TESTING TECHNIQUE AND EQUIPMENT}

\subsubsection{Vickers Microhardness}

Post-irradiation Vickers microhardness testing was performed using a Mitutoyo HV-120 hardness tester in the hot cell as shown in Figure 4. The test procedure was based on the ASTM E384 standard [8] with 1 $\mathrm{kg}$ force and $15 \mathrm{sec}$ dwell time. No sample preparation, e.g. polishing or grinding, was made prior to testing. As shown in Figure 5, four hardness measurements were made for each notch near the middle plane surrounding the end of the initial fatigue precrack. These hardness measurements were carefully chosen as to not affect the crack propagation path during the fracture toughness testing. This practice ensured a statistical measurement of the hardness near the crack initiation site during the following fracture toughness testing. Due to the partially recrystallized nature of the C06M and C36M specimens stemming from the choice of thermomechanical processing parameters used for their original fabrication and small amount of irradiation temperature gradient along the length of the bend bar, it was of vital importance to get microhardness values in regions of the M4CVN bend bar specimens that were representative of the microstructure and irradiation temperature near the end of the initial fatigue precrack. 


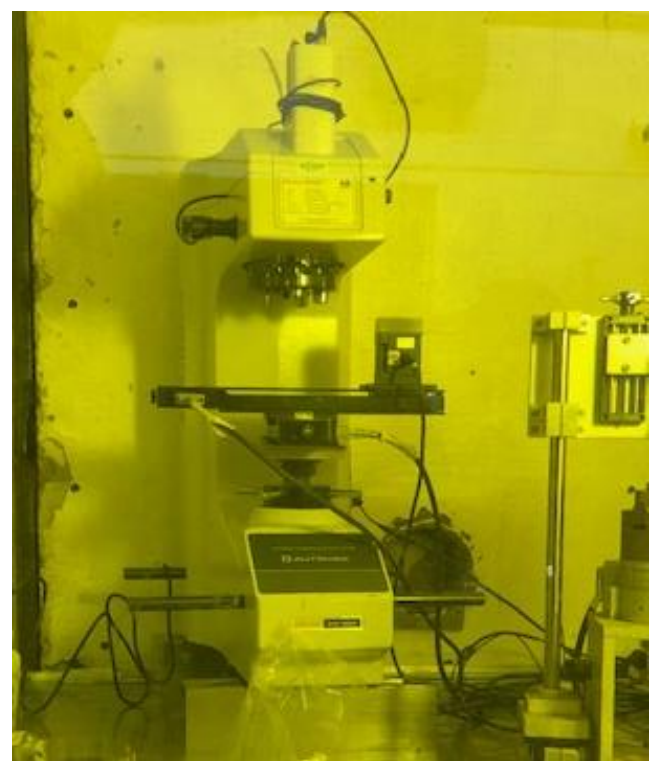

Figure 4. Vickers hardness tester in the hot cell facility

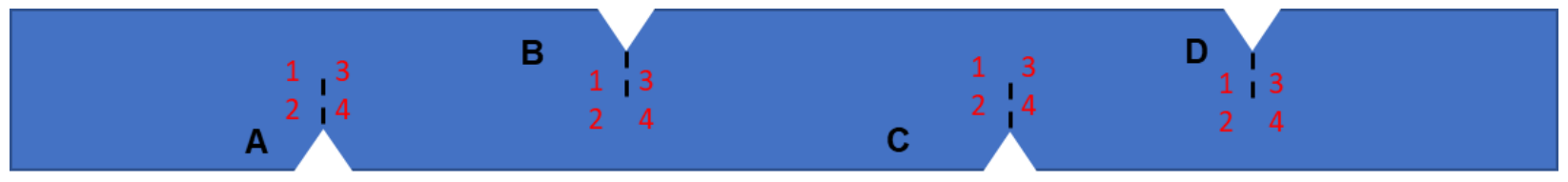

Figure 5. Vickers microhardness indentation pattern for M4CVN bend bar specimens

\subsubsection{Master Curve Transition Fracture Toughness}

The fracture toughness testing was performed using servo-hydraulic frames. The test frame used for unirradiated specimens had $222.4 \mathrm{kN}$ load capacity and the load cell had a calibrated $4.45 \mathrm{kN}$ capacity. The testing temperature was measured directly from a thermocouple spot welded near each specimen notch. For irradiated specimens, testing was performed in the hot cell facility with a $444.8 \mathrm{kN}$ load capacity servo-hydraulic frame with a calibrated load cell rated for $22.25 \mathrm{kN}$. Test temperature was measured from thermocouples spot welded to the end of the indenter tip which was in direct contact with the bend bar specimens in testing (Figure 6) and had been calibrated with a calibration specimen with a spot-welded thermocouple for the entire testing temperature range. For elevated temperature testing, a heat tape was used. Due to the upper operating temperature limit of the deflection gauge, the highest testing temperature was kept below $200^{\circ} \mathrm{C}$.

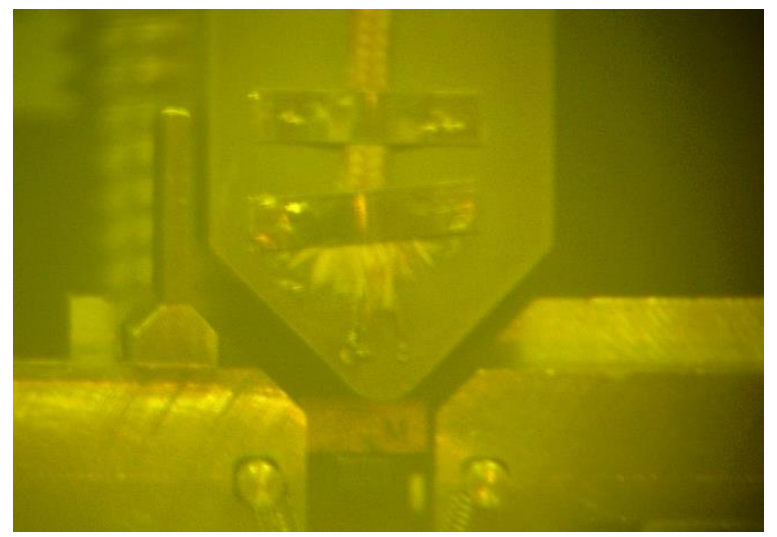

Figure 6. Thermocouples spot welded to the indenter tip in direct contact with the bend bar specimen 
To test M4CVN bend bar specimens, we have designed a dedicated testing fixture shown in Figure 7. The deflection gauge attached to the specimen fixture was used to measure the load-line displacement of the specimen. The push bar can slide left and right and is used to push the specimen against the positioning block such that the specimen notch is aligned with the specimen indenter and the deflection gauge.

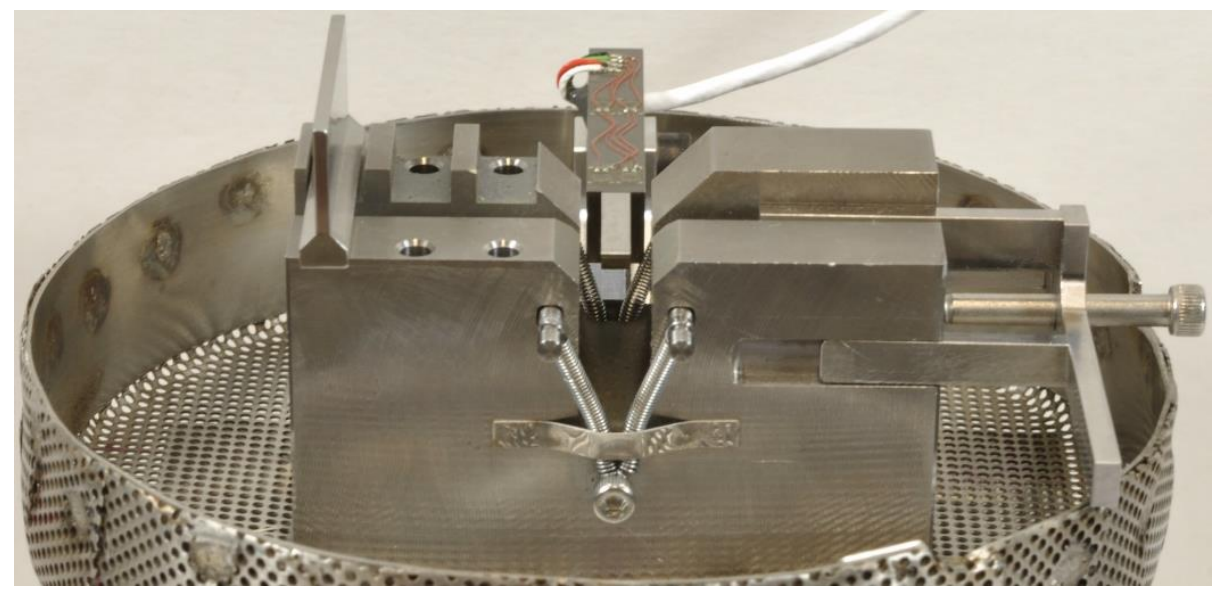

(a)

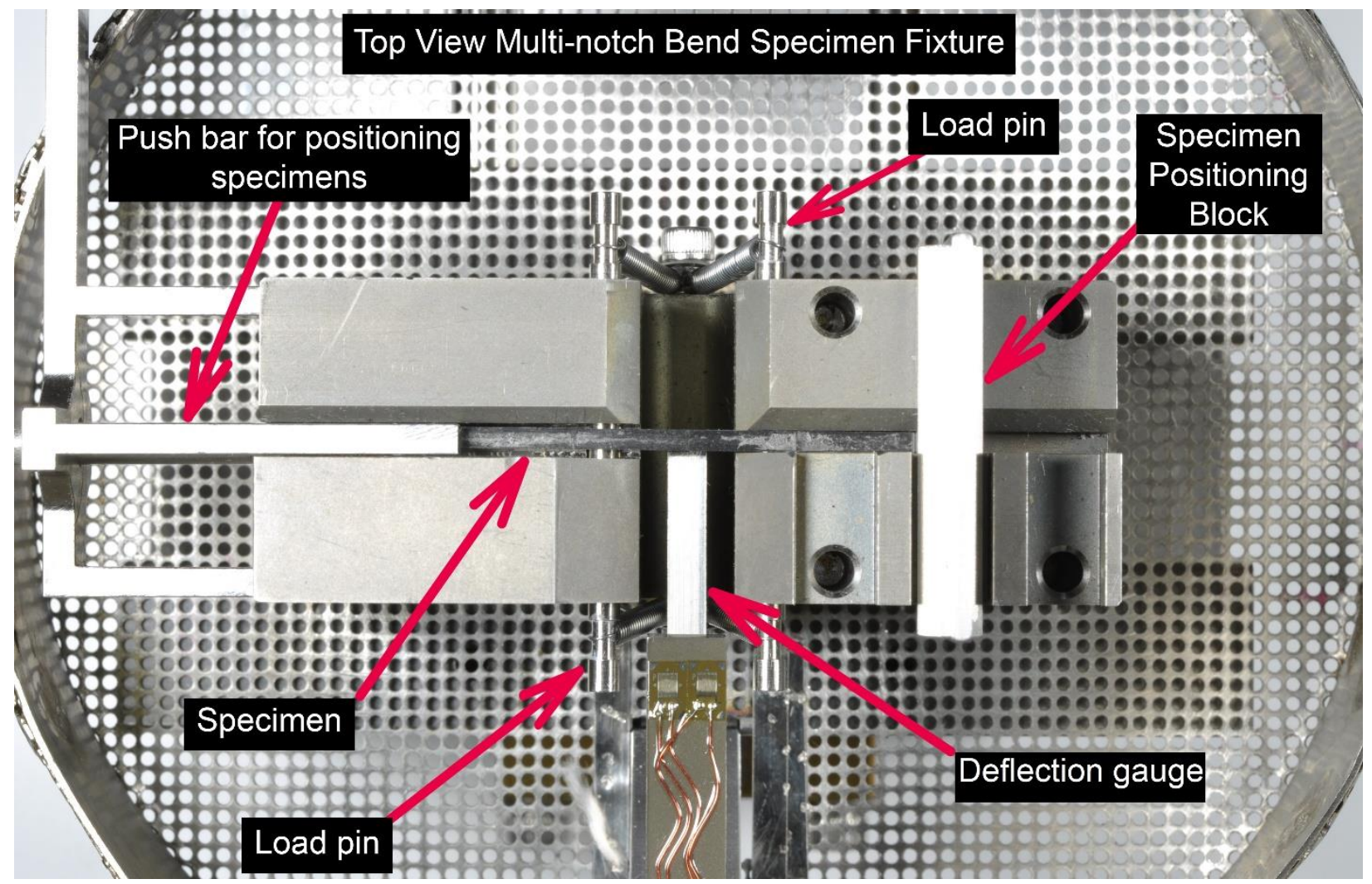

(b)

Figure 7. M4CVN bend bar specimen test fixture. (a) front view, (b) top view

We performed fracture toughness testing according to the ASTM E1921 Master Curve method. The test temperatures were selected by balancing between obtaining as high fracture toughness results as possible and still within the fracture toughness capacity limit $\mathrm{K}_{\text {Jclimit }}$ given in Eq. (1): 


$$
K_{J c \lim i t}=\sqrt{\frac{E b_{O} \sigma_{Y S}}{30\left(1-v^{2}\right)}}
$$

where:

$\mathrm{E}=$ material Young's modulus at the test temperature,

$\mathrm{b}_{0}=$ length for the initial uncracked ligament,

$\sigma_{\mathrm{YS}}=$ material yield strength at the test temperature,

$\mathrm{v}=$ Poisson's ratio.

Each specimen notch was tested until cleavage or $\sim 30 \%$ load drop from the peak load if only ductile crack growth occurred and then the crack length was measured from the fracture surface. The elastic-plastic equivalent stress intensity factor, $\mathrm{K}_{\mathrm{Jc}}$, was derived from the J-integral at the onset of cleavage fracture and size-adjusted to 1T (one-inch thickness) value based on the statistical weakest-link theory:

$$
K_{J C(1 T)}=20+\left[K_{J C(o)}-20\right]\left(\frac{B_{0}}{B_{1 T}}\right)^{1 / 4}
$$

where:

$\mathrm{K}_{\mathrm{Jc}(1 \mathrm{~T})}=\mathrm{K}_{\mathrm{Jc}}$ for a specimen thickness of one inch $\left(\mathrm{B}_{1 \mathrm{~T}}=25.4 \mathrm{~mm}\right)$,

$\mathrm{K}_{\mathrm{Jc}(\mathrm{o})}=\mathrm{K}_{\mathrm{Jc}}$ for a specimen thickness of $\mathrm{B}_{\mathrm{o}}\left(\mathrm{B}_{\mathrm{o}}=1.641 \mathrm{~mm}\right.$ for M4CVN specimens $)$.

We then calculated the Master Curve provisional reference temperature $\mathrm{T}_{\text {oq }}$ using a multi-temperature analysis method in Eq. (3) and $\mathrm{K}_{\mathrm{Jc}}$ data were censored against both the fracture toughness capacity limit $\mathrm{K}_{\mathrm{Jclimit}}$ and the slow stable crack growth limit $\mathrm{K}_{\mathrm{Jc} \Delta \mathrm{a}}$.

$$
\begin{aligned}
& \sum_{i=1}^{N} \delta_{i} \frac{\exp \left[0.019\left(T_{i}-T_{o q}\right)\right]}{11.0+76.7 \exp \left[0.019\left(T_{i}-T_{o q}\right)\right]} \\
& -\sum_{i=1}^{N} \frac{\left(K_{J C(i)}-20\right)^{4} \exp \left[0.019\left(T_{i}-T_{o q}\right)\right]}{\left\{11.0+76.7 \exp \left[0.019\left(T_{i}-T_{o q}\right)\right]\right\}^{5}}=0
\end{aligned}
$$

where:

$\mathrm{N}=$ number of specimens tested,

$\mathrm{T}_{\mathrm{i}}=$ test temperature corresponding to $\mathrm{K}_{\mathrm{Jc}(\mathrm{i})}$,

$\mathrm{K}_{\mathrm{Jc}(\mathrm{i})}=$ either a valid $\mathrm{K}_{\mathrm{Jc}}$ datum or a datum replaced with a censoring value,

$\delta_{\mathrm{i}}=1.0$ if the datum is valid or zero if the datum is a censored value,

$\mathrm{T}_{\mathrm{oq}}=$ Master Curve provisional reference temperature solved by iteration. 


\section{RESULTS AND DISCUSSION}

\subsection{VICKERS MICROHARDNESS}

The Vickers microhardness values for C06M and C36M are summarized below in Figure 8. In the unirradiated state, the microhardness variation between these two model $\mathrm{FeCrAl}$ alloys was minimal. However, due to differences in the fabrication history of C06M and C36M, it is difficult to attribute this small difference in initial hardness to singular changes in the $\mathrm{Cr}$ concentration. The similarity of alloy response to high-temperature irradiation is highlighted by almost identical microhardness values at the $500^{\circ} \mathrm{C}$ irradiation temperature. At $500^{\circ} \mathrm{C}$, no Cr-rich $\alpha^{\prime}$ precipitates are expected based on the $\mathrm{Fe}-\mathrm{Cr}$ and $\mathrm{Fe}-\mathrm{Cr}-\mathrm{Al}$ phase diagrams; furthermore, this irradiation temperature is above that required for dislocation loops to form. Thus, the similar unirradiated microstructures, coupled with the similar alloy compositions, helps explain the identical irradiation response of these alloys at this temperature. At the $315^{\circ} \mathrm{C}$ irradiation temperature, both alloys showed a similar amount of irradiation hardening. Although the microstructures of these specimens have not yet been quantified, it is expected that similar dislocation loop densities will exist. At the lowest irradiation temperature of $166^{\circ} \mathrm{C}$, both alloys showed significant hardening compared with high irradiation temperature cases, which is expected to be due primarily to high densities of refined dislocation loops. Although some $\alpha^{\prime}$ precipitates may have formed at this low temperature due to radiation-assisted Cr-diffusion, a detailed investigation of the propensity for $\alpha^{\prime}$ precipitation is needed to see if ballistic dissolution was dominating at this temperature, thereby destabilizing $\alpha$ 'precipitates and explaining why no increased hardening is seen for C36M in comparison to $\mathrm{C} 06 \mathrm{M}$. Current work is being performed to confirm the underlying mechanisms for these trends.

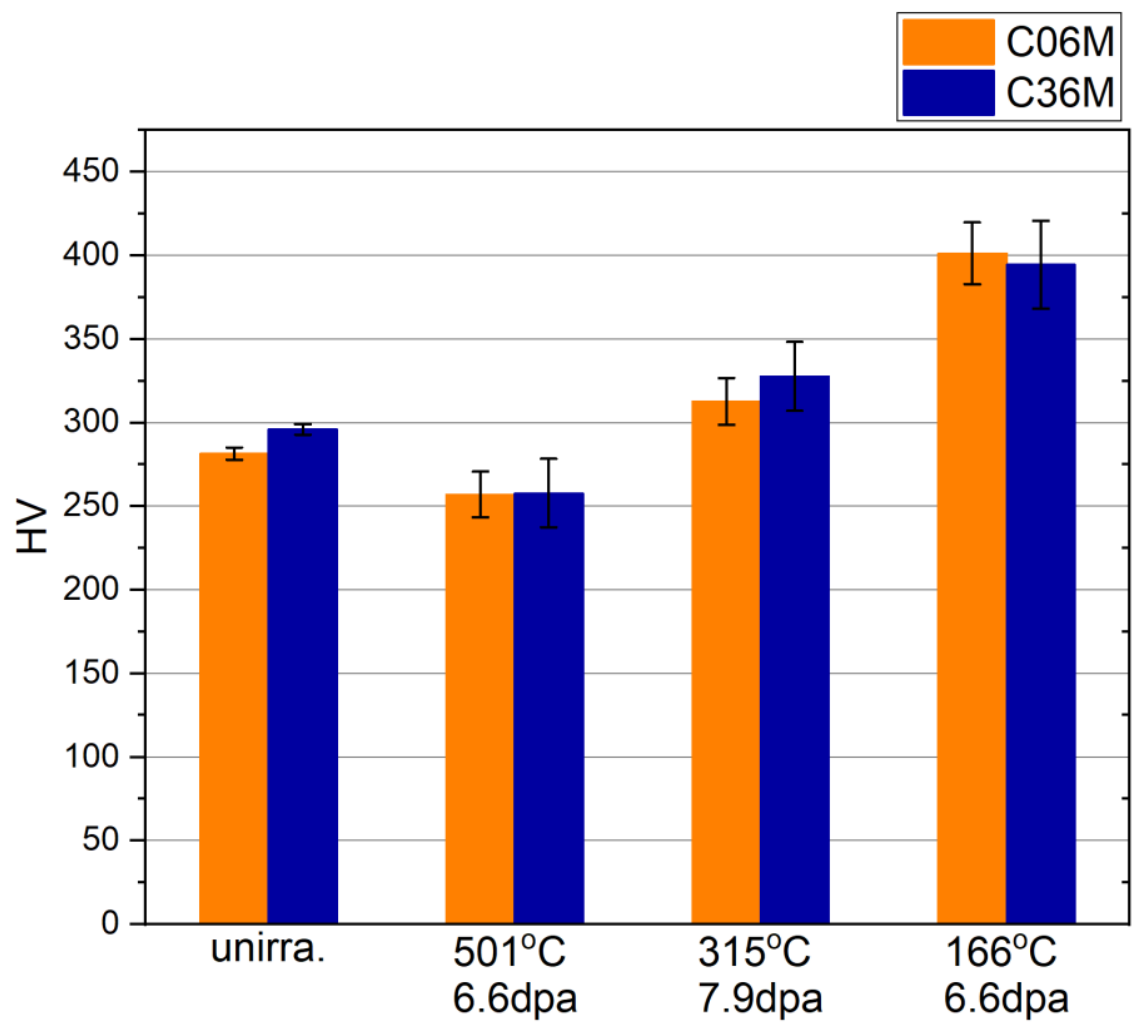

Figure 8. Vickers microhardness results before and after neutron irradiation for C06M and C36M 


\subsection{TRANSITION FRACTURE TOUGHNESS}

The fracture toughness results of C06M and C36M for both unirradiated and irradiation conditions are shown in Figure 9 and Figure 10, respectively. From Eq. (3), we calculated the Master Curve provisional reference temperature, $T_{\mathrm{oq}}$, and then we plotted the Master Curve in Figures 9 and 10 using the following equation:

$$
K_{J c(\text { med })}=30+70 \exp \left[0.019\left(T-T_{O q}\right)\right]
$$

where:

$\mathrm{K}_{\mathrm{Jc}(\mathrm{med})}=$ median fracture toughness for a multi-temperature data set from 1T size specimen, $\mathrm{T}=$ test temperature,

$\mathrm{T}_{\mathrm{oq}}=$ Master Curve provisional reference temperature.

The tolerance bounds were calculated using the equation below:

$$
K_{J C(0 . x x)}=20+\left[\ln \left(\frac{1}{1-0 . x x}\right)\right]^{1 / 4}\left\{11+77 \exp \left[0.019\left(T-T_{o q}\right)\right]\right\}
$$

where:

$0 . x x=$ selected cumulative probability level, e.g., for the $2 \%$ tolerance bound, $0 . x x=0.02$.

Due to the small size of M4CVN specimens, the fracture toughness capacity limit $\mathrm{K}_{\text {Jclimit }}$ of the specimen was very low, which forced the testing in the temperature region more than $50^{\circ} \mathrm{C}$ lower than the derived provisional Master Curve reference temperature, $\mathrm{T}_{0 \mathrm{q}}$. Based on the current ASTM E1921 standard, this violated the minimum testing temperature requirement and therefore the provisional value cannot be qualified as Master Curve reference temperature, $T_{0}$. Nonetheless, most valid fracture toughness data (data points below the blue dashed line) in Figures 9 and 10 are bounded by the $2 \%$ and $98 \%$ tolerance boundaries of the Master Curve. In addition, our past study shows that the Master Curve transition reference temperature determined by the miniature bend bar specimens is essentially the same as that determined by conventional larger size specimens [5, 9-12].

For material $\mathrm{C} 06 \mathrm{M}$, at both $501^{\circ} \mathrm{C}$ and $315^{\circ} \mathrm{C}$ irradiation temperatures, a small amount of irradiation embrittlement, indicated by a small increase in $\mathrm{T}_{\text {oq }}$, was observed. In contrast, for the $166^{\circ} \mathrm{C}$ irradiation temperature, significant irradiation embrittlement, manifested by increase in $\mathrm{T}_{\mathrm{oq}}$ from $110^{\circ} \mathrm{C}$ at the unirradiated condition to $303^{\circ} \mathrm{C}$ at the irradiated condition, was observed. A similar trend of irradiation embrittlement behavior was observed for material C36M as well, i.e., non-significant change in $\mathrm{T}_{\mathrm{oq}}$ for irradiations at $501^{\circ} \mathrm{C}$ and $315^{\circ} \mathrm{C}$ whereas significant irradiation embrittlement for the irradiation at $166^{\circ} \mathrm{C}$. Figure 11 compares the correlation between irradiation hardening and irradiation embrittlement for both materials. A reasonable linear correlation was observed for both materials considering the scatter in Vickers microhardness measurements. Despite a lower initial $\mathrm{T}_{\text {oq }}$ for $\mathrm{C} 06 \mathrm{M}$, the material exhibited a steeper slope for the increase in $\mathrm{T}_{\mathrm{oq}}$ than $\mathrm{C} 36 \mathrm{M}$ for the same amount of irradiation hardening. Additional characterization is needed to understand the underlying mechanisms for the trend. 


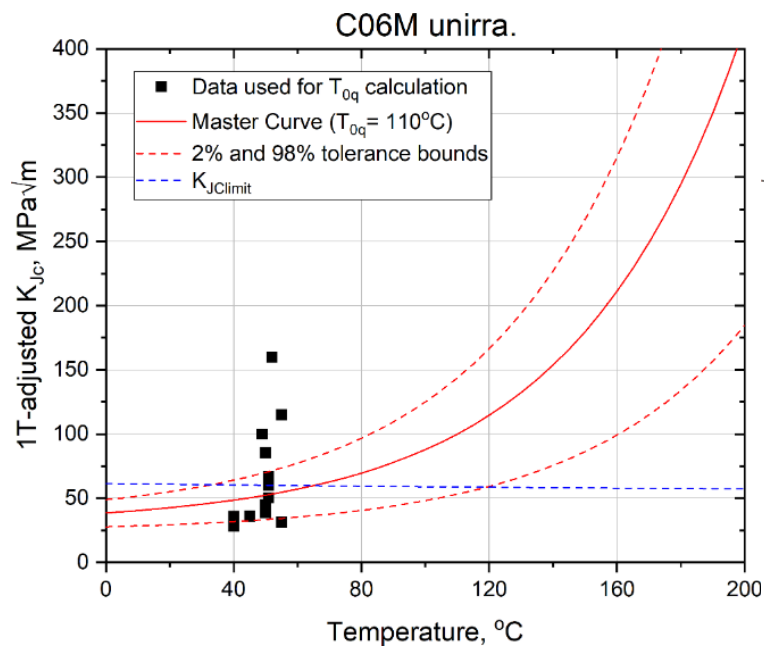

(a)

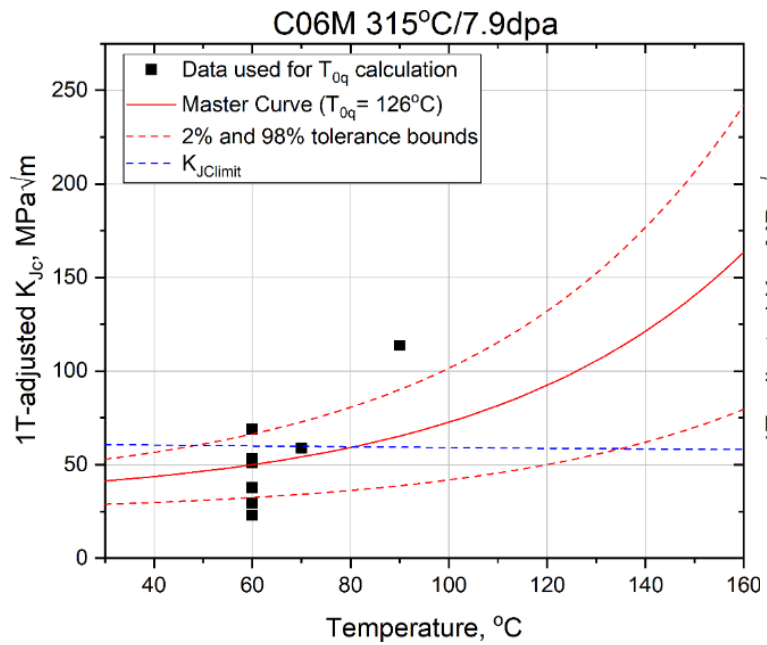

(c)

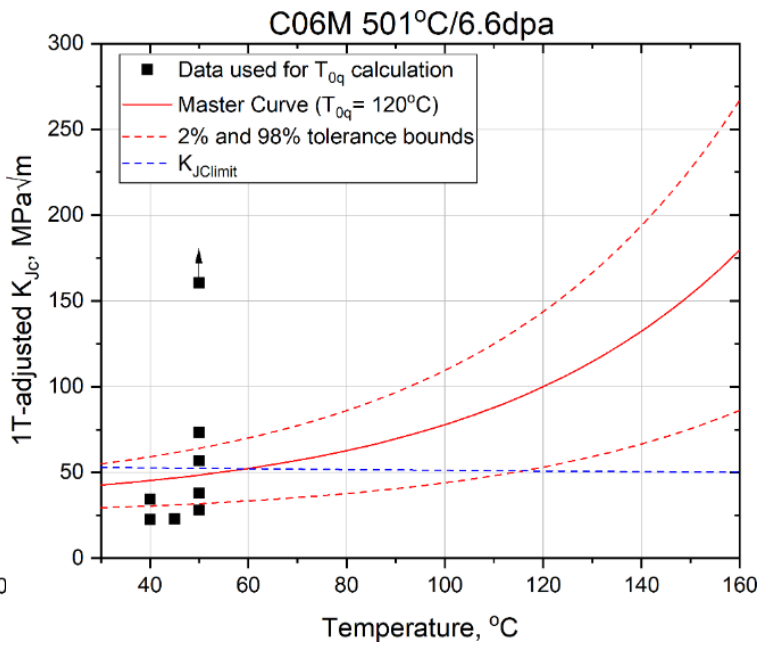

(b)

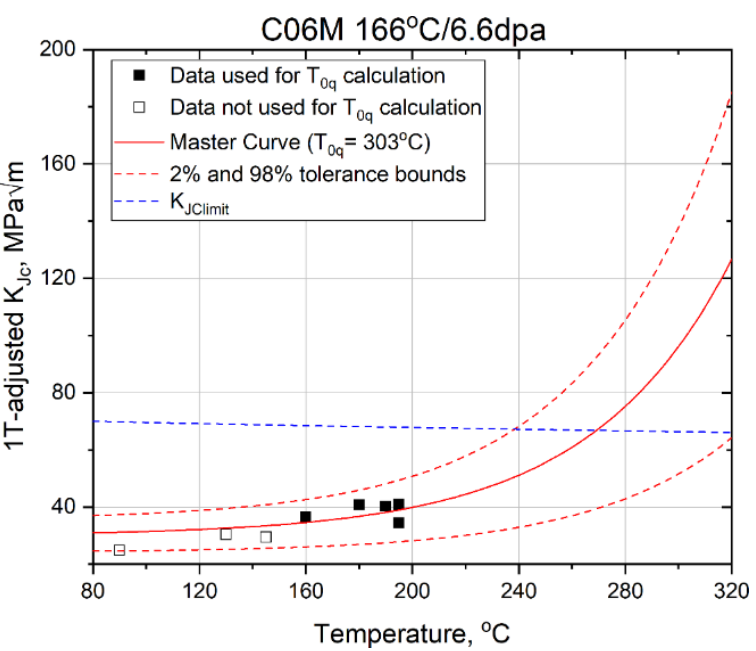

(d)

Figure 9. Master Curve fracture toughness results for C06M. (a) unirradiated, (b) $501^{\circ} \mathrm{C} / 6.6 \mathrm{dpa}$, (c) $315^{\circ} \mathrm{C} / 7.9 \mathrm{dpa}$, (d) $166^{\circ} \mathrm{C} / 6.6 \mathrm{dpa}$

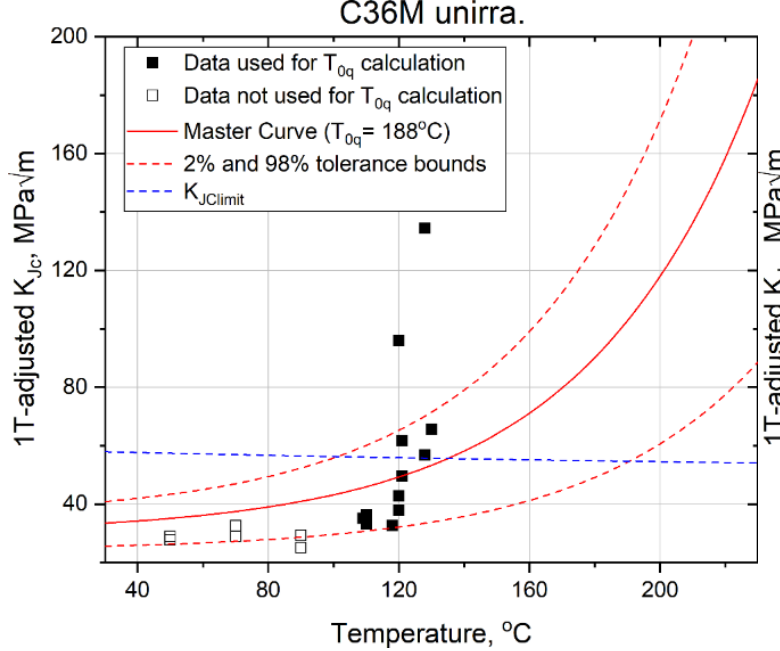

(a)

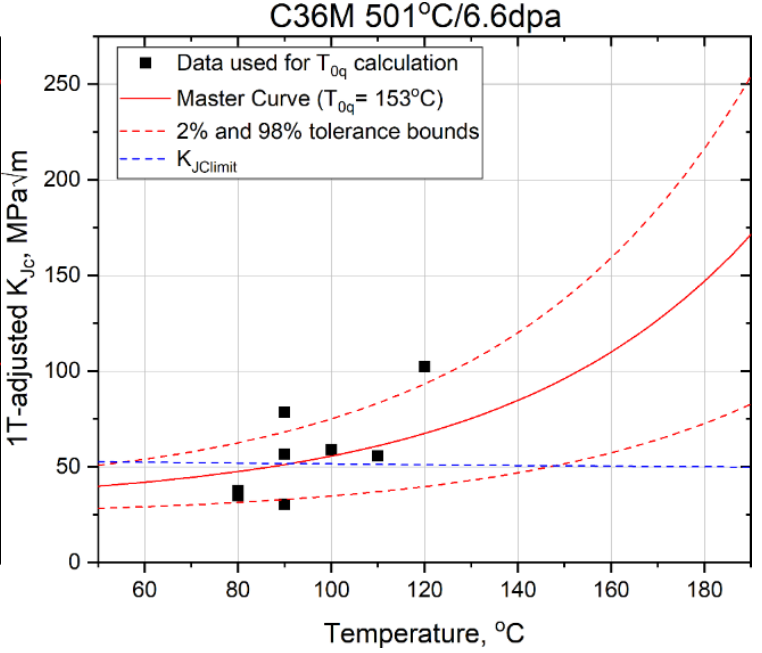

(b) 


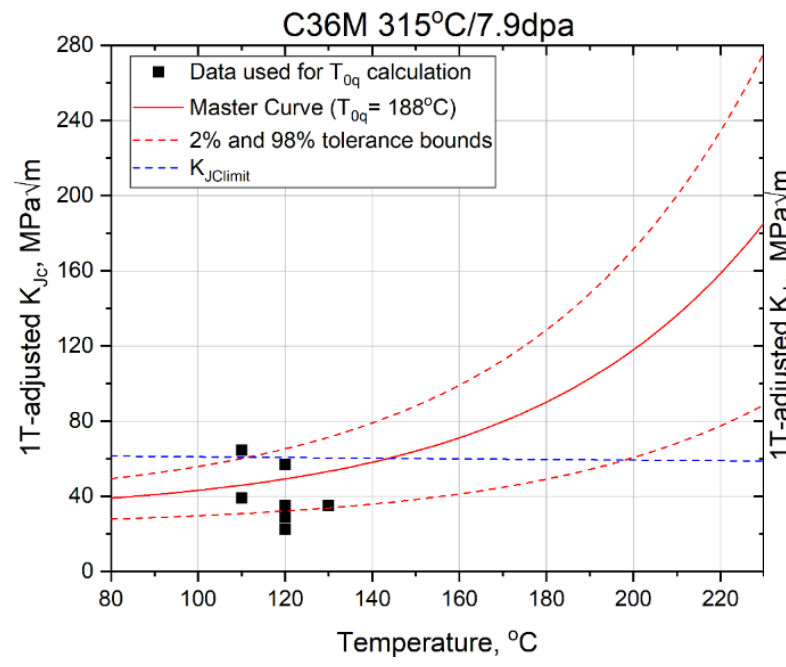

(c)

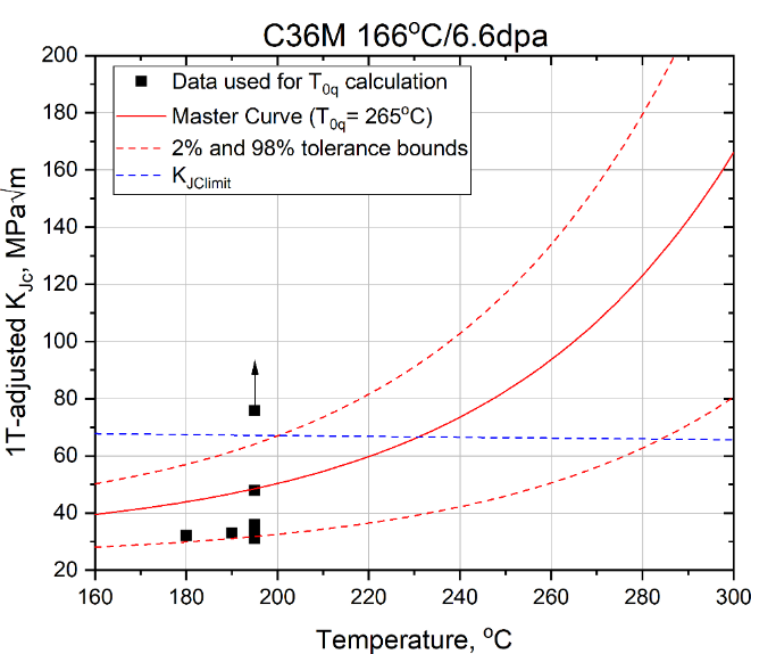

(d)

Figure 10. Master Curve fracture toughness results for C36M. (a) unirradiated, (b) $501^{\circ} \mathrm{C} / 6.6 \mathrm{dpa}$, (c) $315^{\circ} \mathrm{C} / 7.9 \mathrm{dpa}$, (d) $166^{\circ} \mathrm{C} / 6.6 \mathrm{dpa}$

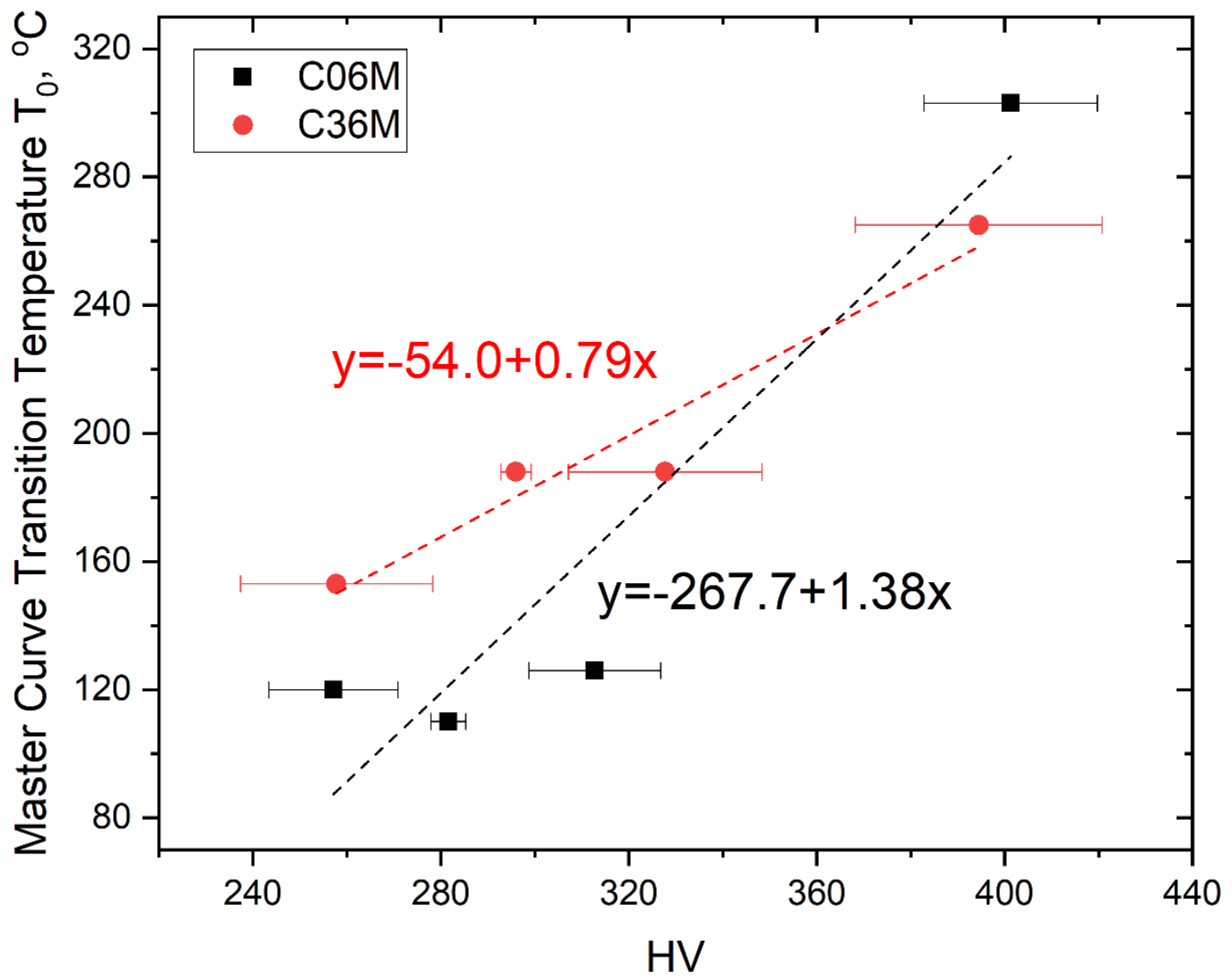

Figure 11. Correlation between microhardness and Master Curve transition temperature $\mathrm{T}_{0}$ for $\mathrm{C} 06 \mathrm{M}$ and $\mathrm{C} 36 \mathrm{M}$ 


\section{CONCLUSIONS}

We performed post-irradiation fracture toughness characterization on two Generation II FeCrAl alloys, i.e., $\mathrm{C} 06 \mathrm{M}$ and $\mathrm{C} 36 \mathrm{M}$. The measured irradiation conditions were: $501^{\circ} \mathrm{C} / 6.6 \mathrm{dpa}, 315^{\circ} \mathrm{C} / 7.9 \mathrm{dpa}$, and $166^{\circ} \mathrm{C} / 6.6 \mathrm{dpa}$. Main conclusions of this study can be summarized as followings:

1) For the unirradiated condition, the Master Curve fracture toughness transition temperature $T_{0}$ was $110^{\circ} \mathrm{C}$ for $\mathrm{C} 06 \mathrm{M}$ and $188^{\circ} \mathrm{C}$ for $\mathrm{C} 36 \mathrm{M}$.

2) Irradiations at $501{ }^{\circ} \mathrm{C}$ and $315^{\circ} \mathrm{C}$ resulted in small changes in $\mathrm{T}_{0}$ from the unirradiated condition for both C06M and C36M.

3) Significant irradiation embrittlement was observed for both $\mathrm{C} 06 \mathrm{M}$ and $\mathrm{C} 36 \mathrm{M}$ for the irradiation at $166^{\circ} \mathrm{C}$ where $\mathrm{T}_{0}$ raised to $303^{\circ} \mathrm{C}$ for $\mathrm{C} 06 \mathrm{M}$ and $265^{\circ} \mathrm{C}$ for $\mathrm{C} 36 \mathrm{M}$.

4) A reasonable linear correlation between the Master Curve fracture toughness transition temperature $\mathrm{T}_{0}$ and Vickers microhardness was observed for both C06M and C36M with C06M showing a steeper increase in $\mathrm{T}_{0}$ for the same amount of irradiation hardening.

\section{REFERENCES}

1. K.G. Field, M.A. Snead, Y. Yamamoto, B.A. Pint, K.A. Terrani, Materials properties of FeCrAl alloys for nuclear power production applications, ORNL/TM-2017/186. (2017). doi:10.2172/1400207.

2. Z. Sun, Y. Yamamoto, X. Chen, Impact toughness of commercial and model FeCrAl alloys, Mater. Sci. Eng. A. (2018). doi:10.1016/J.MSEA.2018.07.074.

3. W. Chubb, S. Alfant, A.A. Bauer, E.J. Jablonowski, F.R. Shober, R.F. Dickerson, Constitution, metallurgy, and oxidation resistance of iron-chromium-aluminum alloys: BMI-1298, (1958).

4. K.G. Field, Y. Yamamoto, R.H. Howard, Status of Post Irradiation Examination of FCAB and FCAT Irradiation Capsules, ORNL/TM-2016/558. (2016).

5. X. Chen, M.A. Sokolov, L.N. Clowers, Y. Katoh, M. Rieth, Master Curve fracture toughness characterization of Eurofer97 steel variants using miniature multi-notch bend bar specimens for fusion applications, Proceedings of the ASME 2018 Pressure Vessels and Piping Conference, PVP2018-85065, July 15-20, 2018, Prague, Czech Republic.

6. ASTM E1921-17a: Standard Test Method for Determination of Reference Temperature, T0, for Ferritic Steels in the Transition Range, ASTM International, West Conshohocken, PA, 2017.

7. A.A. Campbell, W.D. Porter, Y. Katoh, L.L. Snead, Method for analyzing passive silicon carbide thermometry with a continuous dilatometer to determine irradiation temperature, Nucl. Instruments Methods Phys. Res. Sect. B Beam Interact. with Mater. Atoms. 370 (2016) 49-58.

doi:10.1016/j.nimb.2016.01.005.

8. ASTM E384-17, Standard Test Method for Microindentation Hardness of Materials, ASTM International, West Conshohocken, PA, 2017.

9. X. Chen, M.A. Sokolov, A. Bhattacharya, L.N. Clowers, T. Graening, Y. Katoh, M. Rieth, Master Curve Fracture Toughness Characterization of Eurofer97 Steel Variants Using Miniature Multi-notch Bend Bar Specimens for Fusion Applications, Proceedings of the ASME 2019 Pressure Vessels and Piping Conference, PVP2019-93797, July 14-19, 2019, San Antonio, TX, USA.

10. M. Sokolov, H. Tanigawa, Fusion Reactor Materials Program Semiannual Progress Report, DOE/ER0313/41, December 31, 2006, p83.

11. M. Sokolov, H. Tanigawa, Fusion Reactor Materials Program Semiannual Progress Report, DOE/ER0313/33, December 31, 2002, p105. 
12. X. Chen, M.A. Sokolov, K.D. Linton, L.N. Clowers, Y. Katoh, Transition fracture toughness characterization of Eurofer97 steel using pre-cracked miniature multi-notch bend bar specimens, ORNL/LTR-2017/532, November 30, 2017. 